\title{
Predicting Court Outcomes through Political Preferences: The Japanese Supreme Court and the Chaos of 1993
}

\section{Citation}

J. Mark Ramseyer, Predicting Court Outcomes through Political Preferences: The Japanese Supreme Court and the Chaos of 1993, 58 Duke L.J. 1557 (2009).

\section{Published Version}

http://scholarship.law.duke.edu/cgi/viewcontent.cgi?article=1408\&context=dlj

\section{Permanent link}

http://nrs.harvard.edu/urn-3:HUL.InstRepos:10880601

\section{Terms of Use}

This article was downloaded from Harvard University's DASH repository, and is made available under the terms and conditions applicable to Open Access Policy Articles, as set forth at http:// nrs.harvard.edu/urn-3:HUL.InstRepos:dash.current.terms-of-use\#OAP

\section{Share Your Story}

The Harvard community has made this article openly available. Please share how this access benefits you. Submit a story.

Accessibility 


\title{
PREDICTING COURT OUTCOMES THROUGH POLITICAL PREFERENCES: THE JAPANESE SUPREME COURT AND THE CHAOS OF 1993
}

\author{
J. MARK RAMSEYER $\dagger$
}

\begin{abstract}
Empiricists routinely explain politically sensitive decisions of the U.S. federal courts through the party of the executive or legislature appointing the judge. That they can do so reflects the fundamental independence of the courts. After all, appointment politics will predict judicial outcomes only when judges are independent of sitting politicians. Because Japanese Supreme Court justices enjoy an independence similar to that of U.S. federal judges, I use judicial outcomes to ask whether Japanese premiers from different parties have appointed justices with different political preferences.

Although the Liberal Democratic Party (LDP) governed Japan for most of the postwar period, it temporarily lost power in the mid1990s. Elsewhere, Professor Eric Rasmusen and I asked whether the administration of the lower courts changed during this non-LDP hiatus. Here, I explore whether the supreme court changed. More specifically, I ask whether the non-LDP premiers appointed supreme court justices with different policy preferences. I find that they did not.
\end{abstract}

\section{INTRODUCTION}

In universities, scholars try hard to understand why judges decide cases the way they do. In the United States, we find that (in some subsets of cases) we can predict the way federal judges decide cases through proxies for their political preferences. Most obviously,

\footnotetext{
Copyright (C) 2009 by J. Mark Ramseyer.

$\dagger$ Mitsubishi Professor of Japanese Legal Studies, Harvard Law School. I received helpful comments and suggestions from Tom Ginsburg, Frank Upham, and Mitu Gulati and his students at Duke University School of Law and generous financial assistance from the John M. Olin Center for Law, Economics \& Business at Harvard Law School.
} 
sometimes we can predict their decisions through the party of their appointing president or legislature. ${ }^{1}$

These studies work because federal judges are independent and human. In conducting them, we use standard social scientific tools. And social science explains how judges act because it concerns human behavior - and judges are, after all, human beings. As Judge Richard Posner put it, they are "all-too-human workers, responding as other workers do to the conditions of the labor market in which they work." ${ }^{2}$ In a 1993 essay, Posner asked, what do judges maximize? ${ }^{3}$ We in the academy may disagree about the details, but few of us would quarrel with his bottom line: the same thing everybody else does. ${ }^{4}$

Others have sometimes been less sympathetic. When Professor Richard Revesz used the party of the appointing president to predict voting patterns on the D.C. Circuit, ${ }^{5}$ Judge Harry Edwards declared war: it was time to "refute the heedless observations of academic scholars who misconstrue and misunderstand the work of ... judges." When Professors Frank B. Cross and Emerson H. Tiller characterized dissenting judges as whistleblowers, ${ }^{7}$ he dismissed their piece as an "absurd" bit "of sheer speculation."

But perhaps the D.C. judge doth protest too much. And perhaps he also misses a bit of the point. Scholars like Professors Revesz, Cross and Tiller can predict judicial votes through political variables

1. See Jeffrey A. Segal \& Harold J. Spaeth, The Supreme Court and the AtTitudinal Model ReVisited 219, 217-22 (2002) (discussing "the impact of presidential regimes on the Court's behavior"); Tracey E. George, Developing a Positive Theory of Decisionmaking on U.S. Courts of Appeals, 58 OHIO ST. L.J. 1635, 1651 (1998) (“[S]ocial scientists have discovered that the political party of the appointing President is a good proxy for a justice's attitudes."); Andrew D. Martin, Kevin M. Quinn \& Lee Epstein, The Median Justice on the United States Supreme Court, 83 N.C. L. REV. 1275, 1285-87 (2005) (discussing "[t]he use of political party to identify the median Justice"); Jeffrey A. Segal \& Albert D. Cover, Ideological Values and the Votes of U.S. Supreme Court Justices, 83 AM. POL. SCI. REV. 557, 559-62 (1989) (using newspaper editorials to measure judges' values and then finding a correlation between those values and Supreme Court votes).

2. Richard A. Posner, How Judges Think 7 (2008).

3. Richard A. Posner, What Do Judges and Justices Maximize? (The Same Thing Everybody Else Does), 3 SuPREME CT. ECON. REV. 1, 1 (1993).

4. Id.

5. Richard L. Revesz, Environmental Regulation, Ideology, and the D.C. Circuit, 83 VA. L. REV. 1717, 1718-19 (1997).

6. Harry T. Edwards, Collegiality and Decision Making on the D.C. Circuit, 84 VA. L. REV. 1335, 1335 (1998).

7. Frank B. Cross \& Emerson H. Tiller, Judicial Partisanship and Obedience to Legal Doctrine: Whistleblowing on the Federal Courts of Appeals, 107 YALE L.J. 2155, 2159 (1998).

8. Edwards, supra note 6, at 1337. 
precisely because of the fundamental independence of the federal courts. Were courts not independent of sitting politicians, judges could not costlessly indulge their political biases. And if they could not indulge them at low cost, they would not indulge them often. That they act politically in political cases simply reflects their essential independence from incumbent politicians.

I hesitate to stress the point more strongly. One thoughtful reader of an earlier draft described the point as "old hat." All sensible legal scholars know this, he assured me. I take his point. Rather than push the point further, I simply use it to ask how aggressively leftist Japanese politicians tried to assert control over the courts during their time in power in the mid-1990s.

Unlike their lower-court colleagues, ${ }^{9}$ Japanese Supreme Court justices enjoy politically independent careers. Once appointed, they serve until age seventy-and effectively face no incentives tied to their incomes, wealth, or careers. ${ }^{10}$ Accordingly, I use their opinions to explore the way Japanese politicians try (or do not try) to assert control over the courts.

For this exercise, I turn to the few short years in the mid-1990s when three reformist prime ministers briefly broke the hold of what had been the ruling Liberal Democratic Party (LDP). To ask whether these three tried to transform the courts, I ask whether the justices they appointed wrote different opinions from LDP appointees. Because politicians primarily control the Japanese lower courts

9. For discussion of the political management of Japanese lower courts, see generally J. MARK RAMSEYER \& ERIC B. RASMUSEN, MEASURING JUdICIAL INDEPENDENCE: THE POLITICAL ECONOMY OF JUDGING IN JAPAN (2003) [hereinafter RAMSEYER \& RASMUSEN, MeAsuring Judicial IndePendence]; J. Mark Ramseyer \& Eric B. Rasmusen, Political Uncertainty's Effect on Judicial Recruitment and Retention: Japan in the 1990s, 35 J. COMP. ECON. 329 (2007) [hereinafter Ramseyer \& Rasmusen, Political Uncertainty's Effect]; J. Mark Ramseyer \& Eric B. Rasmusen, The Case for Managed Judges: Learning from Japan After the Political Upheaval of 1993, 154 U. PA. L. REV. 1879 (2006) [hereinafter Ramseyer \& Rasmusen, Case for Managed Judges]; J. Mark Ramseyer \& Eric B. Rasmusen, Why Are Japanese Judges So Conservative in Politically Charged Cases?, 95 AM. POL. SCI. REV. 331 (2001) [hereinafter Ramseyer \& Rasmusen, Japanese Judges]; J. Mark Ramseyer \& Eric B. Rasmusen, Why Is the Japanese Conviction Rate So High?, 30 J. LEGAL STUD. 53 (2001) [hereinafter Ramseyer \& Rasmusen, Japanese Conviction Rate]; J. Mark Ramseyer \& Eric B. Rasmusen, Why the Japanese Taxpayer Always Loses, 72 S. CAL. L. REV. 571 (1999) [hereinafter Ramseyer \& Rasmusen, Japanese Taxpayer]; J. Mark Ramseyer \& Eric B. Rasmusen, Judicial Independence in a Civil Law Regime: The Evidence from Japan, 13 J.L. ECON. \& ORG. 259 (1997) [hereinafter Ramseyer \& Rasmusen, Judicial Independence].

10. Saibansho ho [Court Act], Law No. 59 of 1947, art. 50. 
through the supreme court, ${ }^{11}$ a premier who hoped to change the courts would have stacked the supreme court with justices who shared his reformist instincts. Those instincts, in turn, would have reflected a different set of policy preferences from those of the LDP appointees. Given the institutional independence of the supreme court, those different policy preferences would have been observable in the opinions the justices wrote. Were they?

I begin by discussing the ties between career incentives and judicial independence (Part I). I explain Japanese court structure (Parts II and III), and the political turmoil of 1993 (Part IV). I conclude by testing whether the LDP and reformist justices wrote different opinions (Part V).

\section{INDEPENDENCE}

\section{A. Within Markets}

Few scholars would try to use ideological or political variables to predict the way corporate CEOs run their businesses. It is not that CEOs do not hold strong preferences. Like most humans, they hold preferences over a wide range of issues. And like most, they bring these preferences to their jobs.

Nonetheless, scholars seldom try to use ideological or political preferences to explain the way CEOs do their jobs. Even when CEOs hold such preferences over precise issues a business faces, scholars ignore them. They ignore them because they do not matter: the preferences do not explain much that CEOs do.

The reason is simple-CEOs operate under market constraints. There are exceptions, to be sure. Environmentalist executives may locate politically congenial careers in "green" technologies. Leftist financiers may market "social choice" mutual funds. Religiously driven managers may run church nonprofits.

Yet within most industries, market competition prevents executives from much indulging their ideological and political biases. Ultimately, CEOs run their firms within the confines of capital, labor, and service and product markets. If they choose a strategy for ideological rather than economic reasons, they risk losing customers.

11. For a discussion of these mechanisms, see supra Part II.B. Note, however, that politicians could refuse to confirm lower-court judges at the end of their ten-year terms. Saibansho ho [Court Act], art. 40(3). This is rarely observed. RAMSEYER \& RASMUSEN, MEASURING JUDICIAL INDEPENDENCE, supra note 9, at 8. 
Left on their own, they risk running their firm out of business. Fundamentally, incumbent CEOs do not maximize economic returns because they "believe" in those returns more strongly than they believe in ideology or politics. They maximize economic returns because competitive markets weed them out if they do anything else.

\section{B. Within Institutions}

Scholars find politics similarly irrelevant within tightly run organizations. Even in organizations insulated from economic markets, scholars may find employee political preferences mostly beside the point. Take a think tank owned by Party $A$. $A$ maintains the institute to promote its own policies. It does not want its research staff using it to promote the policies of rival Party $B$.

Given this environment, institute employees who championed anything other than Party $A$ policies would find themselves at a dead end. In general, the institute would not promote them as rapidly as their peers. It would not pay them as generously. Should they complete a study that recommended Party $B$ policies, it would tend not to publish it. Whatever private preferences these employees might hold, their published work will tend to endorse $A$ 's policies. Even scholars who knew the employees' private preferences would seldom find them relevant.

Crucial to this equilibrium is Party A's power potentially to intervene in internal institute affairs. ${ }^{12} A$ will actually intervene in matters only occasionally, and only when it needs to demonstrate its power and control. For as long as $A$ can intervene, it will not need actually to do so. Rather than risk $A$ 's punishment, incumbent employees will promote $A$ 's positions on their own. Incumbent employees would likely not hire an outspoken Party $B$ follower who applies for work. Knowing that $A$ had the power to intervene in personnel matters, few $B$ partisans would bother applying for the job anyway. They realize the institute will tend not to promote them, not to pay them well, and not to publish the studies they write. Rather than apply to the institute, they will opt for more gratifying work elsewhere.

12. See Randall L. Calvert, Mark J. Moran \& Barry R. Weingast, Congressional Influence over Policy Making: The Case of the FTC, in CONGRESS: STRUCTURE AND POLICY 493, 514-17 (Mathew D. McCubbins \& Terry Sullivan eds., 1987). 


\section{Within Courts}

1. Independence. Political preferences explain judicial decisions in the U.S. federal courts precisely because-by Constitution, by statute, and by custom-politicians have insulated them from the usual "high-powered" incentives that CEOs and think-tank employees face. Federal judges can decide cases as they please, and suffer no ill effect. Suppose they write an opinion that displeases the president or the Chief Justice or the attorney general or the Speaker of the House. They will not earn a lower salary. They will not miss a promotion, ${ }^{13}$ or find their opinions denied publication. Their court is even less likely to go out of business. Precisely because politicians do not punish a judge for indulging private preferences, ${ }^{14}$ a scholar can sometimes use those preferences to predict how a judge will decide.

2. Dependence. By contrast, suppose a powerful politician (say, the prime minister in a parliamentary government) controlled the courts more closely. Suppose he hired subordinates to monitor the way judges behave. Suppose he controlled resources (like pay scale assignments) that judges valued. And suppose he used the control to promote personal political preferences.

Within this judicial environment, scholars could seldom predict judicial behavior through judicial preferences. In this environment, heterodox judges who indulged their private preferences would find their careers stalled. They might not be appointed to prestigious posts. They might find their salaries frozen. They might not see their opinions published. Realizing the potential cost of heterodoxy, most such judges would keep their preferences to themselves. And contemplating a life of enforced compliance, many more heterodox jurists would opt for life in the private bar instead.

As a result, a judge's political preferences will help predict judicial decisions only when politicians keep the courts independent

13. U.S. judges, however, are not indifferent to the possibility of being appointed to a more prestigious court. See, e.g., Mark A. Cohen, Explaining Judicial Behavior or What's "Unconstitutional" About the Sentencing Commission?, 7 J.L. ECON. \& ORG. 183, 193 (1991) (finding evidence "consistent with the hypothesis that judges are more likely to follow the Administration's wishes when facing the prospect of a promotion to an appeals court position").

14. For a discussion of why U.S. politicians find it advantageous to do so, see TOM Ginsburg, Judicial REVIEW IN NEW DEMOCRACIES: CONSTITUTIONAL COURTS IN Asian CASES 21-33 (2003); F. Andrew Hanssen, Is There a Politically Optimal Level of Judicial Independence?, 94 AM. ECON. REV. 712, 712 (2004); J. Mark Ramseyer, The Puzzling (In)dependence of Courts: A Comparative Approach, 23 J. LEGAL STUD. 721, 741-42 (1994). 
of themselves. Should politicians do so, a judge will find it relatively costless to decide cases according to private preferences. In the routine business of court decisionmaking, he will seldom focus on those preferences. After all, few judges hold heterodox beliefs (whatever those might be) about traffic accident or consumer debt claims. In the unusual but politically newsworthy cases of constitutional moment, however, judges may indeed disagree with each other about how to decide a case. Those disagreements, in turn, will track their private political preferences.

Hence the moral: where politicians keep the courts independent, court outcomes will tend to track private judicial preferences; where politicians do not do so, those private preferences simply will not matter.

\section{THE JAPANESE LOWER COURTS ${ }^{15}$}

\section{A. The Incentives}

Remarkably closely, this account of the Party $A$ think tank captures the internal dynamics of the Japanese lower courts. For most of the past half-century, the courts recruited their lower-court judges from (what was until recently) the sole national law school, the Legal Research \& Training Institute (LRTI). In a typical year, they hired seventy to one hundred new judges. ${ }^{16}$ These men and women (in 1998, 81 percent were still men $)^{17}$ then served a series of renewable ten-year terms. The courts almost always renewed those terms ${ }^{18}$ and most judges quit a few years before the mandatory retirement age of sixtyfive. ${ }^{19}$

15. I take the general description below from RAMSEYER \& RASMUSEN, MEASURING JUDICIAL INDEPENDENCE, supra note 9, at 7-25. For an alternative (but largely consistent) general description, see generally John O. Haley, The Japanese Judiciary: Maintaining Integrity, Autonomy, and the Public Trust, in LAW In JAPAN: A TURNING POINT 99 (Daniel H. Foote ed., 2007).

16. See Zen SAIBANKAN KeIREKI SORAN [OVERVIEW OF CAREERS OF All Judges] (Nihon minshu horitsuka kyokai ed., 4th ed. 2004) (collecting data on all judges, by year).

17. Ramseyer \& Rasmusen, Case for Managed Judges, supra note 9, at 1886 tbl.3.

18. RAMSEYER \& RASMUSEN, MEASURING JUDICIAL INDEPENDENCE, supra note 9, at 8.

19. Saibansho ho [Court Act], Law No. 59 of 1947, art. 50 (setting the mandatory retirement age at sixty-five); J. MARK RAMSEYER \& FRANCES MCCALL RosenbluTH, JAPAN'S POLITICAL MARKETPLACE 154 tbl.8.1 (1993) (demonstrating the practice of early retirement). 
During their careers, lower-court judges moved from post to post and city to city, usually at three-year intervals. ${ }^{20}$ Some posts carried more prestige than others. Among the most coveted were those with administrative power: chief judgeships, for example, or positions in the judicial administrative headquarters known as the Supreme Court Secretariat. ${ }^{21}$ Among the least desirable were the branch offices and family courts. ${ }^{22}$

Similarly, some cities offered more appeal than others. Like other professionals, most Japanese judges preferred to live in the urban centers. ${ }^{23}$ There, they found the best preparatory schools for their children and the greatest amenities for themselves. ${ }^{24}$ Among those centers, most judges preferred Tokyo, if not Tokyo then Osaka, and if not Osaka then one of the regional centers. ${ }^{25}$ Should a Tokyo judge find himself posted to a small town, he typically left his family in Tokyo. ${ }^{26} \mathrm{He}$ moved there alone, and then prayed for a reassignment to Tokyo three years hence.

And some judges earned more than others, even more than others of the same age. Granted, Article 80 of the Constitution declares that "judges of the inferior courts shall receive ... adequate compensation which shall not be decreased. ${ }^{, 27}$ But to protect against pay cuts is one thing. To guarantee uniform increases is quite another. Subject to minor qualifications, all U.S. federal judges on the courts of appeals earn the same pay. As life-long employees, Japanese judges do not. They start their careers at low pay. ${ }^{28}$ If they climb the pay scale rapidly they will in time earn attractive salaries, but the Constitution does not guarantee a rapid climb. By controlling the pace at which they climb the scale, the courts can use the highest of the high-powered incentives to control the way their judges behave.

\footnotetext{
20. RAMSEYER \& ROSENBLUTH, supra note 19 , at 156.

21. Id.

22. Id.

23. RAMSEYER \& RASMUSEN, MEASURING JUDICIAL INDEPENDENCE, supra note 9 , at 11.

24. Id. at $11-12$.

25. Id.

26. Id. at 12 .

27. KENPÕ, art. 80.

28. For the pay scale as of the late 1980s, see RAMSEYER \& ROSENBLUTH, supra note 19, at 155 tbl.8.2.
} 


\section{B. Control}

1. Administrative Ties. Decisions about which judge to post in which position to which city at what pay grade are controlled by the judges in the Secretariat. ${ }^{29}$ These judges too hold standard lower-court appointments and serve in the Secretariat for the standard three-year term-but the Secretariat is not a standard post. Instead, it is among the fairest posts of them all. Judges named to the Secretariat are judges in a hurry. Typically, they will move in and out of the most coveted Tokyo and Osaka jobs, rotate through a series of increasingly prestigious appointments, and cap their careers as a district court chief judge or high (that is, intermediate appellate) court president (that is, chief judge)..$^{30}$

At the Secretariat, judges decide the personnel questions that determine their colleagues' careers. In doing so, they answer to the Secretariat's own Secretary General. The Secretary General too is a career judge, typically in his fifties. After running the Secretariat for several years, he will be named President of the Tokyo or Osaka High Court (there are seven high courts, but these presidencies are the most avidly desired). Often, he will then be appointed a justice to the supreme court itself.

The secretary general answers to the supreme court chief justice. Put conversely, the chief justice monitors the secretary general; the secretary general supervises the judges staffing the Secretariat; and the Secretariat judges make the decisions that determine the fate of their peers in the lower courts. ${ }^{31}$

2. Political Ties. The ruling LDP does indeed control the Japanese lower courts. Formally, it controls the courts indirectlymostly through its power to appoint the fifteen supreme court justices, including the administratively crucial chief justice. ${ }^{32}$ The LDP controls the cabinet, after all, and the cabinet selects the fifteen justices to the court. ${ }^{33}$ To avoid the "Harry Blackmun problem," it names its justices late in their lives. Appoint a forty-five-year-old justice, after all, and risk ongoing changes in political beliefs several times before retirement (though Justice Blackmun himself was over

29. See RAMSEYER \& RASMUSEN, MEASURING JUDICIAL INDEPENDENCE, supra note 9, at $9-13$.

30. For a comparison of two judicial careers, see $i d$. at 14 .

31. Saibansho ho [Court Act], Law No. 59 of 1947, art. 53. 
sixty). To mitigate this risk, the LDP can and does appoint justices close to their mandatory retirement at age seventy. From 1983 through 1992, it named twenty-six men to the supreme court. It named one at age sixty, one at sixty-one, one at sixty-two, and the rest between sixty-three and sixty-eight (with a mean of 64.3). ${ }^{34}$

Through the Diet, the LDP can also constrain the ability of the judges to make law. Japan maintains a parliamentary system of government. For much of the postwar period, Japanese voters elected enough legislators from the LDP for the party to field cabinets without a coalition. ${ }^{35}$ If heterodox judges tried to shape the case law, the party stood ready to reverse them through legislation. ${ }^{36}$ Even were higher courts not to overturn the judges' opinions on appeal (and usually they would), the legislature could vitiate their prospective impacts by statute.

\section{Quality and Quantity}

1. Quality Control. With this control, the LDP does not primarily manipulate the political complexion of judicial opinions. After all, most opinions have no serious political complexion to manipulate. Instead, the LDP offers voters high quality. It routes the rare politically loaded disputes out of the courts, and (through the Secretariat) induces the courts to handle the remaining "ordinary" cases expeditiously, intelligently, honestly, and consistently. ${ }^{37}$

Japanese judges resolve most cases with dispatch. Despite having many fewer judges per capita than the United States, the Japanese courts decide cases at the pace of the high-quality federal courts in

32. For a detailed discussion of this and other potential mechanisms of control, see RAMSEYER \& ROSENBLUTH, supra note 19, at 152-53, 161-81.

33. KENPÕ, art. 79; Saibansho ho [Court Act], art. 39.

34. Ramseyer \& Rasmusen, Case for Managed Judges, supra note 9, at 1882 tbl.1, 1883 tbl.2.

35. RAMSEYER \& ROSENBLUTH, supra note 19, at 19 fig.2.2.

36. See McNollgast, Conditions for Judicial Independence, 15 J. CONTEMP. LEGAL ISSUES 105, 112 (2006) ("[T]he more closely aligned and coordinated are the political branches, the more likely they are to agree on policy outcomes, which enables them to reduce the number of issues on which the Court can exercise meaningful independent discretion.").

37. This is an evaluation with which Haley apparently agrees. See Haley, supra note 15, at 120-21 (describing the effect of the "shadow of potential political intrusion" on judges). For discussion of Haley's work, see Frank K. Upham, Political Lackeys or Faithful Public Servants?: Two Views of the Japanese Judiciary, 30 LAW \& SOC. INQUIRY 421, 441-54 (2005). 
the United States. ${ }^{38}$ According to court insiders, the Secretariat maintains this pace by collecting docket-clearance rates on all judges and using them to reward and punish. Unfortunately, the rates are not public. The (plausibly correlated) rates at which judges write published opinions are indeed public, however, and judges who write more publishable opinions per year do find themselves appointed to the better posts. ${ }^{39}$

Second, Japanese judges decide like cases similarly. Probably, the Secretariat rewards its judges for following precedent. After all, Japanese courts are nothing if not predictable. Curiously, however, judges who publish opinions that are reversed on appeal do not visibly suffer in their careers. ${ }^{40}$ In fact, though, the case reporters print only a small minority of decisions ${ }^{41}$ and perhaps a judge who writes publishable opinions that are reversed on appeal is still producing higher-quality output than a judge who publishes nothing at all.

In any event, Japanese courts work hard to maintain consistency across opinions. The Secretariat occasionally operates workshops on frequently litigated legal issues. And, by way of example, Daniel Foote has nicely documented how judges deliberately engineered consistency to the booming traffic-accident litigation in the 1970s. ${ }^{42}$

2. The Returns to Talent. The Secretariat maintains this high level of quality by rewarding talent. Put most pedantically, it appoints to the most desirable posts and cities those judges who exhibit traits most closely correlated with the diligence and intelligence necessary to run high-quality courts. Put more colloquially, the Secretariat rewards the smart and hard working.

Consider judicial backgrounds. Smart and hard-working judges tend to have been smart and hard-working students. And smart and hard-working students tend to do well on important exams. The

38. J. MARK RAMSEYer \& MinORU NAKAZATO, JAPANESE LAw: AN ECONOMIC APPROACH 140 tbl.6.1A, 141 tbl.6.1B (1999).

39. See RAMSEYER \& RASMUSEN, MEASURING JUdiCIAL INDEPENDENCE, supra note 9 , at 54 tbl.3.4, 67 tbl.4.2, 71 tbl.4.5, 90 tbl.5.3, 94 tbl.5.5 (describing the effects of opinion writing on judicial careers).

40. Id. at $76-80$.

41. In 2000, for example, the district courts disposed of 530,000 civil cases. See Tsujo dai Isshinjiken no Shukyoku Sojinin [Summary Court Statistics] (2006), http://www.courts.go.jp/ sihotokei/nenpo/pdf. Based on a search in the Hanrei taikei database, the public and private reporters together published 1452 district court opinions during that year.

42. Daniel H. Foote, Resolution of Traffic Accident Disputes and Judicial Activism in Japan, 25 L. JAPAN 19, 24-30 (1995). 
qualities that enable students to score high on exams, in other words, also enable them as judges to handle cases quickly and accurately. And the judges who succeeded most prominently as students tend to succeed most prominently in the courts.

First, the judges who attended the schools with the most selective entrance examinations enjoy the most successful careers. They begin at the most coveted courts. Throughout their career, they spend more time in prestigious assignments, and more time in the desirable cities. They climb the pay scale more rapidly. And they are more likely to conclude their careers with an appointment to a Chief Judgeship. ${ }^{43}$

The private market generates an analogous result. Provided they practice in Tokyo, attorneys from the University of Tokyo earn the highest incomes. The university has long maintained the most restrictive entrance exam. Given the prestige of the courts, a high fraction of judges have traditionally come from the University of Tokyo. ${ }^{44}$ And just as University of Tokyo graduates on the bench tend to do better than their colleagues, University of Tokyo lawyers in the competitive private market in Tokyo tend to earn higher incomes than their counterparts from other universities. ${ }^{45}$

Second, the judges who passed the LRTI entrance exam most quickly have the most successful careers. During most of the past half-century, the passage rate on the exam hovered in the 1-3 percent range. ${ }^{46}$ Most exam takers never passed, and the average lawyer finally passed it only after first failing six or seven times. ${ }^{47}$ Consistent again with the high prestige of the courts, the average judge passed it more quickly than the average lawyer: the average judge failed it "only" three to five times. ${ }^{48}$ But among the judges, those who failed it fewer times started at the best courts, spent more time in prestigious

43. For a description of this point, see generally RAMSEYER \& RASMUSEN, MEASURING JUDICIAL INDEPENDENCE, supra note 9.

44. Ramseyer \& Rasmusen, Political Uncertainty's Effect, supra note 9, at 335 tbl.1A.

45. Minoru Nakazato, J. Mark Ramseyer \& Eric B. Rasmusen, The Industrial Organization of the Japanese Bar 1 (Harvard Law \& Econ., Discussion Paper No. 559, 2006), available at http://ssrn.com/abstract=951622.

46. See id. (manuscript at 2) (describing the LRTI exam as one "that 97-99 percent of the applicants failed").

47. Id. (manuscript at 8-9).

48. Ramseyer \& Rasmusen, Political Uncertainty's Effect, supra note 9, at 335 tbl.1A. 
posts, spent more time in desirable cities, climbed the pay scale more rapidly, and more likely ended their careers as chief judges. ${ }^{49}$

Again, the private market generates an analogous result. Whether in Tokyo or the smaller cities, the lawyers who passed the exam most quickly report the highest incomes later in their careers. ${ }^{50}$ Passing exams requires intelligence and hard work, and those qualities are ones that employers and clients value. Whether on the market or in the courts, the smartest and hardest-working jurists enjoy the most successful careers.

\section{POLITICS IN THE JAPANESE LOWER COURTS}

\section{A. Structure}

Institutional control over Japanese lower courts may improve quality, but it also involves political motivations. The Secretariat does not just manipulate incentives to promote speed and accuracy. It also manipulates them to promote LDP policy. And precisely because the LDP - through the Secretariat-controls crucial incentives within the lower courts, scholars will find it hard to use the political preferences of individual lower-court judges to predict their decisions.

Again, the controls are indirect. The LDP can appoint to the supreme court justices who share its political philosophy. Through that Chief Justice, it can monitor and control the Secretary General of the Secretariat. Through the secretary general, it can set the standards by which the Secretariat staff (judges all) reward and punish individual lower court judges. Through those standards, it can structure a judiciary in which the loyal do well and the heterodox suffer. Through its control over the Diet, it can reverse by statute any case law that a renegade judge might try to make. And because it can do all this, the heterodox will tend to avoid careers in the courts. For a card-carrying Marxist, a career in the Japanese courts is just not a whole lot of fun.

In short, in Japanese lower courts, neither judicial output nor expressed judicial preferences will show much political variation. The case law will reflect LDP policies. The sitting judges will express LDP policies publicly. And most of those judges will even hold LDP policies privately. Regress the case law on potential indices of judicial

49. RAMSEYER \& RASMUSEN, MEASURING JUDICIAL INDEPENDENCE, supra note 9, at 42 tbl.2.7, 53 tbl.3.3, 54 tbl.3.4, 75 tbl.4.7, 90 tbl.5.3, 92 tbl.5.4, 112 tbl.6.4.

50. Nakazato et al., supra note 45, at 17 tbl.3. 
political preference, and insignificant results will usually follow. Although he characterizes the situation as showing independence, Professor John Haley nicely describes the mechanics at play:

The potential for partisan or other political intervention motivates the judges assigned to judicial administration to be more vigilant than perhaps they might otherwise be to ensure that the judiciary enjoys the highest levels of public trust. Thus acceptability of judges to politicians has to be viewed in relation to the similar accountability of politicians to the public.... Individual judges thus function within the shadow of potential political intrusion. They cannot help but be aware that in adjudicating highly publicized, politically sensitive cases, they can be held professionally accountable for their decisions. ${ }^{51}$

He then concludes, "Judges themselves, however, exercise the oversight, not politicians directly or indirectly." ${ }^{, 52}$ In effect, Professor Haley describes "indirect" but straightforward-and potentially extremely effective-political oversight.

\section{B. Enforcement}

It was not always so. The current U.S.-imposed (formally Alliedimposed) Constitution took effect on May 3, 1947 under conservative Shigeru Yoshida's first cabinet. Fielding a coalition government, Socialist Tetsu Katayama replaced him a few days later, and held power for about ten months. In August of that year, he appointed the first fifteen justices to the court. ${ }^{53}$

Back in power in March 1948, Yoshida did not immediately focus on the courts. He had other worries: inflation ran over 50 percent; the Americans had bombed the economy back to the 1930s; his conservative allies stood in disgrace; Allied occupiers were executing the military elite and planning massively to purge the political and business elite; the Americans intended to demand draconian

51. Haley, supra note 15, at 120-21; see also John O. Haley, 30 J. JAPANESE STUD. 235, 239-40 (2004) (book review) ("[T]he actions of Japan's senior judges can be readily explained by concern over any possible public perception of judicial corruption or incompetence or that judges might act out of partisan preference or extreme ideological commitment.”).

52. Haley, supra note 15 , at 121.

53. NIHON KINDAI SHI JITEN [DICTIONARY OF MODERN JAPANESE HiSTORY] 696-702 (Kyoto daigaku bungakubu ed., 1958). 
reparations and liquidate the 500 biggest Japanese firms. ${ }^{54}$ With crises like these, few prime ministers would have worried about enforcing any orthodoxy in the courts.

Yet with the conservative government probably mandating only haphazard conformity, some jurists on the fringe left found the courts an attractive career. From the 1950s through the mid-1960s, a steady stream of jurists from the Communist-affiliated Young Jurists League (YJL) joined the courts. By 1968, about 12 percent of the incoming judges were YJL members. ${ }^{55}$ Only as the LDP extended its hold into the courts did leftist jurists begin to find them uncongenial.

In time, the YJL judges would suffer career penalties. As the LDP strengthened its control over personnel matters, Professor Eric Rasmusen and I find that the YJL judges began to be posted to inferior positions. Talent and effort held constant, they found themselves named to less prestigious positions, and sent to less attractive cities. ${ }^{56}$

When these politically heterodox judges tried to express their personal preferences in their work, they suffered. Granted, they seldom had reason to express those preferences. Most litigation involved no political issues of moment. But over the politically most sensitive disputes, the judges did have reason to indulge their politics. And when they wrote opinions that deviated from the position held by the LDP leadership, they suffered in their careers. For example, Professor Rasmusen and I find penalties in the careers of judges who

1. Acquitted leftist political candidates prosecuted for violating the statutory ban on door-to-door canvassing, ${ }^{57}$

54. See generally Yoshiro Miwa \& J. Mark Ramseyer, The Good Occupation (Harvard Law \& Econ., Discussion Paper No. 514, 2005), available at http://ssrn.com/abstract=729463 (describing the general situation surrounding the Allied occupation of Japan).

55. Ramseyer \& Rasmusen, Case for Managed Judges, supra note 9, at 1886 tbl.3.

56. RAMSEYER \& RASMUSEN, MEASURING JUDICIAL INDEPENDENCE, supra note 9, at 42 tbl.2.7, 54 tbl.3.4, 90 tbl.5.3, 94 tbl.5.5, 112 tbl.6.4, 115 tbl.6.5. We also find that they climbed the pay scale more slowly than equally qualified conservative peers. Id. at 41 tbl.2.6. But see Kentaro Fukumoto \& Mikitaka Masuyama, Judging Political Promotion of Judges: Survival Analysis, Split Population Model and Matching Method 1-24 (2006) (unpublished manuscript), available at http://www-cc.gakushuin.ac.jp/ e982440/research/FKMM-APSA06.pdf (arguing that, although it is more difficult for the leftist judges to get on the track to a prestigious post, there is no evidence of discrimination with respect to the timing of promotion once they do get on the track).

57. RAMSEYER \& RASMUSEN, MEASURING JUdiCIAL INDEPENDENCE, supra note 9, at 58-60; Ramseyer \& Rasmusen, Judicial Independence, supra note 9, at 283-85. 
2. Upheld apportionment-based attacks on LDP electoral victories, during the years when the LDP relied on a rural base, ${ }^{58}$

3. Upheld constitutional challenges to the Japanese military; ${ }^{59}$

4. Enforced politically motivated injunctions against the government. ${ }^{6}$

Disproportionately, these judges spent more time during the decade after writing the opinion in undesirable positions, and less time in more attractive ones.

IV. 1993

\section{A. Change $e^{61}$}

It was the worst of times-at least for the LDP.

After dominating politics for nearly four decades, the LDP entered the 1990s with a wide range of problems. To pay for its lavish pork-barrel projects, it had enacted a sales tax that alienated a broad swath of voters. Under U.S. pressure, it had imposed trade and investment controls that threatened key constituents. With the end of the Cold War, it had lost any urgency to its anticommunist agenda. As rural families migrated to the cities, it found its agricultural base increasingly irrelevant. When its famously relaxed approach to matters financial generated a series of bribery scandals, it lost key leaders. And as the country spiraled into recession, it could no longer even promise prosperity.

Within this crisis, in 1993 old rivals decided to settle scores. Onetime LDP prime-ministerial candidate Ichiro Ozawa engineered a noconfidence vote, quit the party, and organized a new organization around his old-time protégés. In the election that followed, he and his allies did well, while the rump LDP lost badly. The party's rivals regrouped around Ozawa and another renegade LDP, politician Morihiro Hosokawa, and threw it out of power.

58. RAMSEYER \& RASMUSEn, MEASURING JUdiCIAL INDEPENDENCE, supra note 9, at 68-73; Ramseyer \& Rasmusen, Japanese Judges, supra note 9, at 339 tbl.2.

59. RAMSEYER \& RASMUSEN, MEASURING JUDICIAL INDEPENDENCE, supra note 9, at 64-68; Ramseyer \& Rasmusen, Japanese Judges, supra note 9, at 338 tbl.1.

60. RAMSEYER \& RASMUSEN, MEASURING JUDICIAL INDEPENDENCE, supra note 9, at 73-76; Ramseyer \& Rasmusen, Japanese Judges, supra note 9, at 340 tbl.3.

61. See Ramseyer \& Rasmusen, Case for Managed Judges, supra note 9, at 1892-93; Ramseyer \& Rasmusen, Political Uncertainty's Effect, supra note 9, at 332-33. 
Championing a reformist agenda, Hosokawa took control. Ozawa remained the kingpin, however, and even as Prime Minister Hosokawa never escaped his influence. Within months, his coalition unraveled. His successor (ex-LDP politician Tsutomu Hata) lasted barely two months.

In this chaos, the Socialists struck a deal with the LDP. Their leader, Tomiichi Murayama, became prime minister-the first Socialist to do so since Katayama. Murayama governed through a coalition that included the LDP, however, and even this arrangement quickly disintegrated. He implemented little of the Socialist agenda, and by 1996 the LDP was back in power. It has controlled the Cabinet ever since.

Cabinets thus followed the following stages: (a) the LDP controlled the government from 1955 through July 1993; (b) Hosokawa, Hata, and Murayama followed in quick succession; and (c) the LDP returned to power in January 1996. At the supreme court: (a) Hosokawa appointed four justices; (b) Hata appointed none; and (c) Murayama appointed five justices.

\section{B. The Lower Courts}

Elsewhere, Professor Rasmusen and I explore the effect of the 1993-96 turmoil on the lower courts. We find little to report. On the one hand, the courts retained their bias against leftist judges. ${ }^{62}$ Some of the YJL judges from the 1960s, for example, still served in the courts. During the decades leading up to 1993, they endured career penalties. Relative to their more conservative colleagues, they languished in less prestigious posts in less desirable cities.

Much as the Hosokawa-Murayama cabinets mighthypothetically-have tried to abolish this anti-leftist penalty, the bias survived the 1993 crisis. Had the reformists intervened in judicial personnel matters (or had the courts anticipated their intervention), the courts might have changed their relative treatment of YJL and non-YJL judges. They did not: indices of industry and intelligence held constant, after 1993 YJL judges continued to languish in less attractive posts. ${ }^{63}$

62. Ramseyer \& Rasmusen, Case for Managed Judges, supra note 9, at 1922-25.

63. On the other hand, the post-1993 courts may have found it marginally harder to retain and recruit the most talented jurists. If incumbent judges believed that nothing had changed in the wake of 1993, then (economic circumstances held constant) the courts should not have found it harder to retain them. If potential applicants believed that nothing had changed, then 


\section{1993 AND THE SUPREME COURT}

\section{A. The Issue}

The anti-leftist bias in the lower courts survived the 1990s. Apparently, the reformists did not successfully transform the courts. But did they try?

Had the reformists wanted to change the lower courts, in part they would have worked through the supreme court. They would have found it hard. Although the cabinet controls the lower courts, it primarily (not exclusively) controls them through its power to appoint the supreme court associate justices (who police the case law through their power to reverse) and the chief justice (who supervises the secretary general). Not until September 1995 had the reformers named a majority to the court. And not until November 1995 had they named a chief justice. By January 1996, the LDP was back in power. $^{64}$

Perhaps, however, the reformists never seriously attempted to reform the courts. The lower courts would have changed radically only if the reformists had appointed transformative justices to the supreme court. Did they?

Because supreme court justices serve until mandatory retirement at age seventy, they face few (if any) of the incentives that structure lower court careers. Once elected-to put it most bluntly-they are independent. Because of that independence, any political differences among them could appear in their opinions (as is the case in the U.S. federal courts). To test whether Hosokawa and Murayama tried to transform the lower courts, I thus ask whether the justices they appointed wrote different opinions from their predecessors. In Section B, I first outline the work and composition of the court. ${ }^{65}$ I then examine the opinions that the justices actually wrote ${ }^{66}$ and the voting patterns they exhibited. ${ }^{67}$

\footnotetext{
the courts should not have found it harder to recruit talent. Yet some evidence-weak to be sure-suggests that after 1993 the courts did find it harder to retain and recruit the most talented jurists. Apparently, conservative jurists saw too great a risk that reformist politicians might begin to restructure the courts to stay. Their leftist peers saw too small a chance to apply. See generally Ramseyer \& Rasmusen, Political Uncertainty's Effect, supra note 9 (describing the political influences on the composition of the judiciary in Japan in the 1990s).

64. ZEN SAIBANKAN KEIREKI SORAN, supra note 16, at 357-58.

65. See infra Part V.B.

66. See infra Part V.C.

67. See infra Part V.D.
} 


\section{B. Introduction}

Consider, first, some preliminary background.

\section{Workload.}

a. Panels. By statute, the Japanese Supreme Court hears most appeals in one of three five-justice panels. When a dispute raises the constitutionality of a statute or regulation, the court handles it en banc. ${ }^{68}$ When it concerns only legal (rather than constitutional) issues, the court handles it on one of the three panels.

Such may be what the law requires, but the Japanese Supreme Court actually hears almost no cases en banc. ${ }^{69}$ In 1990, it published no en banc opinions at all. In 1995 it filed two and in 2000 one. $^{70}$ Whatever the statutory pretext, the Japanese Supreme Court disposes of nearly all its cases through its five-justice panels.

b. Discretionary Appeals. By the terms of the Civil Procedure Code, the supreme court's work should have fallen dramatically in 1998. Until that year, the court heard all appeals-it exercised no certiorari-like discretion to decline a case. ${ }^{71}$ Since 1998 , it can refuse to hear cases that raise merely legal-rather than constitutionalissues. ${ }^{72}$ Only constitutional cases can it refuse to decline, and the data on en banc decisions suggest such constitutional cases simply do not exist.

But if such is what the law implies, such is not what common sense demands. Before 1998, the court may not have had the discretion to dismiss an appeal, but it could (and often did, I have been assured in casual conversation) simply opine, "Affirmed for reasons given by the court below." After 1998 the court may have the discretion not to hear an appeal, but it must (if it hopes to exercise that discretion intelligently) still review an appeal to decide whether it wants to dismiss it. Pre- or post-1998, the amount of work involved in deciding whether to write a serious opinion should have remained

68. Saibansho ho [Court Act], Law No. 59 of 1947, art. 10.

69. I take the number of opinions from a search of the Hanrei Taikei database. The database compiles the opinions published in all major private and public case reporters. It remains theoretically possible that the Court published other en banc opinions that no reporter bothered to compile. Given that most en banc Supreme Court opinions would be among the most newsworthy opinions in courts, this is highly unlikely.

70. See infra Table 1, Panel A: Opinions Published by the Supreme Court.

71. Minji sosho ho [Code of Civil Procedure], Law No. 29 of 1890, art. 394.

72. Minsohú, art. 312(a), 317(b), 318. 
roughly unchanged. And pre- or post-1998, the amount of work in actually writing the opinion about the disputes it does treat seriously should have remained unchanged as well.

Table 1. Selected Summary Statistics

\begin{tabular}{|c|c|c|c|c|c|c|c|c|c|}
\hline \multicolumn{10}{|c|}{ A. Opinions Published by Supreme Court } \\
\hline & \multirow{2}{*}{\multicolumn{3}{|c|}{ Court Opinions }} & \multicolumn{6}{|c|}{ Cases with at Least One } \\
\hline & & & & \multicolumn{3}{|c|}{ Dissent } & \multicolumn{3}{|c|}{ Concurrence } \\
\hline & 1990 & 1995 & 2000 & 1990 & 1995 & 2000 & 1990 & 1995 & 2000 \\
\hline Panel 1 & 76 & 42 & 56 & 1 & 1 & 7 & 0 & 0 & 3 \\
\hline Panel 2 & 60 & 56 & 64 & 3 & 1 & 1 & 1 & 0 & 4 \\
\hline Panel 3 & 67 & 70 & 54 & 3 & 0 & 1 & 2 & 5 & 3 \\
\hline En banc & 0 & 2 & 1 & 0 & 1 & 1 & 0 & 1 & 0 \\
\hline Total & 203 & 168 & 174 & 7 & 3 & 10 & 3 & 6 & 10 \\
\hline
\end{tabular}

\begin{tabular}{|l|l|l|l|}
\hline \multicolumn{5}{|l|}{ B. Appeals Filed with the Supreme Court } \\
\hline & 1990 & 1995 & 2000 \\
\hline Civil \& Adm & 3109 & 4219 & 6476 \\
\hline Criminal & 1913 & 1858 & 2901 \\
\hline Total & 5022 & 6077 & 9377 \\
\hline
\end{tabular}

\begin{tabular}{|l|l|l|l|l|l|}
\hline C. Reformist Appointees to the Supreme Court \\
\hline $\begin{array}{l}\text { Justice } \\
\text { Appointed }\end{array}$ & Age & University & Career & $\begin{array}{l}\text { Predecessor } \\
\text { Career }\end{array}$ \\
\hline Hosokawa Cabinet \\
\hline Hideo Chigusa & $9 / 93$ & 61 & Tokyo U & Judge & Judge \\
\hline Shigeharu Negishi & $1 / 94$ & 61 & Tokyo U & Prosecutor & Prosecutor \\
\hline Hisako Takahashi & $2 / 94$ & 66 & Tokyo U & Bureaucrat & Bureaucrat \\
\hline Yukinobu Ozaki & $2 / 94$ & 64 & Tokyo U & Lawyer & Lawyer \\
\hline Murayama Cabinet & $7 / 94$ & 62 & Kyoto U & Lawyer & Lawyer \\
\hline Shin'ichi Kaai & $2 / 95$ & 64 & Hosei U & Lawyer & Lawyer \\
\hline Mitsuo Endo & $8 / 95$ & 62 & N.A. & Prosecutor & Prosecutor \\
\hline Kazutomo Ijima & $9 / 95$ & 60 & Tokyo U & Bureaucrat & Bureaucrat \\
\hline Hiroshi Fukuda & $11 / 95$ & 63 & Kyoto U & Judge & Judge \\
\hline Masao Fujii
\end{tabular}

Sources: Hanrei taikei [Case Compendium] (Tokyo: Daiichi hoki, updated);

Saiko saibansho jimuso kyoku, ed., Shiho tokei nempo [Legal Statistics Annual] (Tokyo: Hosokai, various years); Nihon minshu horitsuka kyokai, ed., Zen saibankan keireki soran [Overview of Careers of All Japanese Judges] (Tokyo: Nihon minshu horitsuka kyokai, 4th ed., 2004).

And indeed, the number of cases in which the court writes a serious opinion has stayed approximately constant. From 1990 to 1995, litigants increased the number of appeals they filed by about 20 percent. From 1995 to 2000, they increased it by over 50 percent. 
Despite the fact that the court had new legal authority to refuse their appeals, they filed half again as many appeals. ${ }^{73}$

Table 2. Opinions by LDP and Reformist Justices: All Panels

\begin{tabular}{|l|c|l|l|l|l|l|}
\hline & $\mathrm{n}$ & $\begin{array}{l}\text { Mean Maj. } \\
\text { Ops. }\end{array}$ & $\begin{array}{l}\text { Mean } \\
\text { Dissents }\end{array}$ & $\begin{array}{l}\text { Mean } \\
\text { Concur. }\end{array}$ & $\begin{array}{l}\text { Private } \\
\text { Reporter \% }\end{array}$ & $\begin{array}{l}\text { All Off'l } \\
\text { Reporters \% }\end{array}$ \\
\hline Appointed by: & 28 & 161.14 & 1.43 & 1.36 & 9.46 & 69.47 \\
\hline LDP & 4 & 173.25 & 1.25 & 1.50 & 6.32 & 72.36 \\
\hline Hosokawa & 5 & 191.40 & 1.60 & 1.80 & 2.84 & 62.36 \\
\hline Murayama & 5 Statistics \\
\hline Background: & 13 & 159.46 & 2.38 & 1.62 & 8.21 & 68.91 \\
\hline Lawyer & 5 & 178.60 & .40 & 1.20 & 5.64 & 67.73 \\
\hline Prosecutor & 12 & 163.33 & .75 & .92 & 9.45 & 70.31 \\
\hline Judge & 7 & 176.57 & 1.57 & 2.14 & 8.00 & 66.88 \\
\hline Other background &
\end{tabular}

\begin{tabular}{|l|l|l|l|l|}
\hline B. Regressions & $\begin{array}{l}\text { (2) Total } \\
\text { Dependent } \\
\text { Variable }\end{array}$ & $\begin{array}{l}\text { (1) Total } \\
\text { Dissents }\end{array}$ & $\begin{array}{l}\text { (3) Total } \\
\text { Private Rptr. }\end{array}$ & $\begin{array}{l}\text { (4) Total Official } \\
\text { Rptr. }\end{array}$ \\
\hline LDP Appointee & $-.099(0.17)$ & $-.333(0.46)$ & $7.397(3.10)^{* * *}$ & $3.292(0.74)$ \\
\hline Lawyer & $1.658(2.60)^{* *}$ & $.359(0.46)$ & $-.440(0.17)$ & $-3.480(0.73)$ \\
\hline Prosecutor & $-.317(0.39)$ & $.049(0.05)$ & $-2.997(0.91)$ & $-3.754(0.61)$ \\
\hline Other backgrd & $.863(1.18)$ & $1.012(1.12)$ & $-.756(0.26)$ & $-5.078(0.93)$ \\
\hline Decisions & $-.001(0.18)$ & $-.008(0.94)$ & $.042(1.43)$ & $.674(12.33)^{* * *}$ \\
\hline Adj. R2 & .13 & -.08 & .17 & .83 \\
\hline
\end{tabular}

\begin{tabular}{|l|l|l|l|l|}
\hline Dependent Variable & Dissent \% & Concur. \% & Priv. Rptr. \% & Off'l Rptr. \% \\
\hline LDP Appointee & $.017(0.05)$ & $.219(0.33)$ & $4.405(2.97)^{* * *}$ & $2.351(0.79)$ \\
\hline Lawyer & $1.146(3.06)^{* * *}$ & $.810(1.15)$ & $.159(0.10)$ & $-1.366(0.43)$ \\
\hline Prosecutor & $-.173(0.35)$ & $.156(0.17)$ & $-1.671(0.80)$ & $-2.148(0.51)$ \\
\hline Other backgrd & $.678(1.54)$ & $.742(0.90)$ & $.190(0.10)$ & $-3.262(0.87)$ \\
\hline Adj. R2 & .21 & -.07 & .17 & -.08 \\
\hline
\end{tabular}

Notes: The regressions include the 37 justices appointed between 1983 and 1995 other than the two Chief Justices (who have greater administrative responsibilities). For each Justice, I include all opinions published during his or her first three years on the bench. "Official Reporter" figures include all opinions published in any official reporter. "Private Reporter" figures include those opinions published in either of the two principal private reporters (Hanrei jiho or Hanrei taimuzu) but not in an official reporter.

For appointments, the omitted variable is an appointment by one of the two reformist cabinets. For the background variables, the omitted variable is a background as a career judge.

$n=35 . * * *, * * *$ : significant at the 10, 5 and 1 percent levels, respectively. All regressions include a constant term.

Regressions are OLS, with t-statistics in parenthesis.

Sources: See Table 1.

73. See infra Table 1, Panel B: Appeals Filed with the Supreme Court. 
In fact, however, the court did not substantially change the number of serious opinions it issued. In 1990, it published about 200 cases (some of those very short). It published about 170 in 1995, and about 170 in $2000 .{ }^{74}$ The number of appeals filed may have risen-but the number of opinions published stayed about the same.

c. Dissents. Supreme court justices rarely write dissenting or concurring opinions. Lower court judges never do, but even supreme court justices write them only rarely. Of the 168 opinions in 1995, only three included any dissents. Of the 174 opinions in 2000 , only 10 did. $^{75}$

What is more, the justices who did not come from careers in the lower courts or prosecutorial offices wrote most of the dissents. Of the thirty-seven justices appointed between 1983 and 1995, the former lawyers wrote a mean 2.38 dissents and 1.62 concurrences during their first three years on the bench; the former prosecutors wrote a mean 0.40 dissents and 1.20 concurrences, and the former lower-court judges wrote a mean 0.75 dissents and 0.92 concurrences. $^{76}$

2. Background Careers. The reformist governments of Hosokawa and Murayama appointed justices with the same backgrounds as did their predecessors. Fundamentally, they continued the customary (but not legally mandated) practice of maintaining professional slots. Justices who came from the professional judiciary they replaced with other professional judges. Former prosecutors they replaced with other prosecutors. And career lawyers they replaced with other lawyers. ${ }^{77}$

A government intent on changing the political complexion of the courts would have done otherwise. Under the nearly four-decadelong LDP rule, jurists sharing LDP policy preferences disproportionately would have self-selected into the bureaucracy and the courts. Those with opposition sympathies would have taken (and did take) jobs in the bar or on university faculties. A reformist hoping to stack the court with like-minded judges would thus have named more lawyers or professors. Neither Hosokawa nor Murayama did so. ${ }^{78}$

74. See infra Table 1, Panel A: Opinions Published by the Supreme Court.

75. See infra Table 1, Panel A: Opinions Published by the Supreme Court.

76. See infra Table 2, Panel A: Summary Statistics. For statistical significance, see infra Table 2, Panel B: Regressions.

77. See infra Table 1, Panel C: Reformist Appointees to the Supreme Court.

78. See infra Table 1, Panel C: Reformist Appointees to the Supreme Court. 
3. Age at Appointment. Had the reformists hoped to extend their influence in the courts beyond their expected tenure, they would have appointed young justices. American Presidents do this routinely, of course. John Roberts Jr. was fifty when appointed in 2005; Samuel Alito was fifty-five when appointed in 2006. Even Socialist Katayama in 1947 appointed some justices as young as fifty-three (the mean age was fifty-nine). ${ }^{79}$

Hosokawa and Murayama did not do this. Hosokawa appointed his four at a mean age of 63.0 (range 61-66), and Murayama his five at 62.2 (range 60-64) ${ }^{80}$ Given that supreme court justices face mandatory retirement at age seventy, all Hosokawa-Murayama appointees were gone by 2005 .

4. University Background. University background says nothing about politics. Among University of Tokyo alumni, reformist prime ministers could have chosen either capitalists or communists. The University of Tokyo regularly sends its graduates to the bureaucracy and the exchange-listed corporate ranks. But it counts many Marxists among its faculty and alumni as well-even the chair (as of late 2008) of the Japan Communist Party Central Committee, Kazuo Shii.

In any event, Hosokawa and Murayama continued the meritocratic emphasis of their predecessors. Hosokawa chose all of his justices from the University of Tokyo. Of the four appointees on whom university background is public, Murayama took one from the University of Tokyo and two from its close competitor, the University of Kyoto. ${ }^{81}$

\section{Opinions Published}

In Panel B of Table 2, I ask whether the reformist-appointed justices wrote different opinions than their LDP-appointed colleagues did. Again, I take the thirty-seven justices named between 1983 and 1995: twenty-eight were appointed by LDP prime ministers, four by Hosokawa, and five by Murayama. Because of their greater administrative workload, I exclude the two chief justices. For each justice, I examine the opinions they published during his first three years on the bench.

79. See ZEN SAIBANKAN KEIREKI SORAN, supra note 16.

80. See infra Table 1, Panel C: Reformist Appointees to the Supreme Court.

81. See infra Table 1, Panel C: Reformist Appointees to the Supreme Court. 
In Column (1), I regress the number of dissents individual justices published against the cabinet that appointed them (the omitted category is appointment by Hosokawa or Murayama). I add additional variables for their professional backgrounds (the omitted category is judge) and the total number of decisions in which they participated.

If the reformist-appointed justices decided cases differently than their LDP colleagues, they should have written more dissents (after all, they were in the minority during the first post-1993 years). They did not: the coefficient on LDP appointment is insignificantly different from 0 . In a second set of regressions, I use as dependent variable the percentage (rather than number) of dissents a justice wrote (among his total output). The coefficient on LDP remains insignificant: reformist-appointed justices did not dissent more often than their predecessors.

The LDP justices would have dominated the court most strongly during the first years of the Hosokawa administration. After all, they constituted the largest block during those early years. In other regressions (not reported), I disaggregate the Hosokawa and Murayama justices, and ask whether the former were most likely to dissent. They were not.

In Column (2), I regress the number of concurrences (and percentage of concurrences) against a justice's appointing cabinet. Again, the coefficient on LDP appointment is insignificant: the reformist appointees did not write more concurrences than the LDP appointees.

The private case reporters print opinions their publishers find newsworthy, while the official reporters print opinions selected by Secretariat staff. During the reformist cabinets, lower-court judges hired during the LDP years still controlled the Secretariat. Suppose reformist-appointed justices wrote opinions that flouted LDP preferences. If they did, the major private reporters would have found them newsworthy, while the official reporters would have hesitated to grant them their imprimatur.

In Column (3) I take as my dependent variable the number of opinions published in at least one of the two principal private reporters (Hanrei taimuzu or Hanrei jiho) but not in any of the official reporters. I then regress this count against the party that appointed the justice. Curiously, the coefficient on LDP-appointment is significantly positive: the LDP appointed justices were more likely 
than their reformist colleagues to have opinions published by the major private but not official reporters.

In Column (4), I regress the number of opinions published in an official reporter against the party that appointed the justice. The coefficient on the justice's appointing party is insignificant: LDPappointed justices were no more likely than their reformist colleagues to obtain the imprimatur of official publication.

\section{Voting Alignments}

If the reformist-appointed justices brought a distinctive policy perspective to their work, they should have tended to vote as a block. Disproportionately, they should have voted with each other and against their LDP-appointed colleagues.

To explore this hypothesis, in Table 3 I take all twelve en banc opinions published between January 1, 1993 and December 31, 2002 that included a dissenting or concurring opinion. As Panel A shows, both the LDP and the "reform" blocks of justices routinely split their votes. In general, a justice appointed by Hosokawa or Murayama seems as likely to have voted with the LDP justices as with the other Hosokawa-Murayama appointees.

In Panel B, I report the correlation coefficients (and $p$-values) for a given justice's vote and the percentage of other LDP-appointed or reform-appointed justices voting in the same direction. ${ }^{82}$ According to Panel B.1, any given LDP justice's vote may be more strongly correlated with the votes of the reformist-appointed justices than with the other LDP appointees. According to Panel B.2, the correlation coefficients between any reformist-appointee's vote and the percentage of LDP-appointees and reform-appointees voting in the same direction are indistinguishable.

82. For example, the correlation coefficient between a given LDP appointee's vote for the majority and the percentage of other LDP justices who voted for the majority was -.04 $(p$ value $=.7)$. The correlation coefficient between his vote for the dissent and the percentage of other LDP justices who voted for the dissent is -.05 ( $p$ value $=.6$ ). The discrepancy between the two correlation matrices comes from the fact that the percentages are of the other LDP justices, not all LDP justices. A concurrence is counted as a vote for the majority. 
Table 3. Opinions by LDP and Reformist Justices: En Banc Panels

\begin{tabular}{|c|c|c|c|c|}
\hline \multicolumn{5}{|c|}{ A. Summary Statistics } \\
\hline $\begin{array}{l}\text { Hanrei taikei ID } \\
\text { Number }\end{array}$ & LDP Justices & Reform Justices & $\begin{array}{l}\text { LDP Majority } \\
\text { yotes }\end{array}$ & $\begin{array}{l}\text { Reform Majority } \\
\text { votes }\end{array}$ \\
\hline 28020801 & 6 & 9 & 4 & 9 \\
\hline 28011240 & 6 & 9 & 5 & 4 \\
\hline 28011109 & 6 & 9 & 6 & 9 \\
\hline 27827501 & 9 & 6 & 7 & 3 \\
\hline 28072380 & 12 & 3 & 12 & 3 \\
\hline 28060668 & 10 & 5 & 8 & 4 \\
\hline 28060669 & 10 & 5 & 6 & 3 \\
\hline 28051944 & 9 & 6 & 7 & 3 \\
\hline 28042712 & 9 & 6 & 9 & 6 \\
\hline 28042663 & 8 & 6 & 6 & 3 \\
\hline 28042637 & 8 & 6 & 6 & 3 \\
\hline 28033415 & 8 & 7 & 6 & 4 \\
\hline
\end{tabular}

\begin{tabular}{|c|c|c|c|c|c|c|c|}
\hline \multirow{2}{*}{\multicolumn{8}{|c|}{ B. Correlation Matrices }} \\
\hline & & \multicolumn{6}{|c|}{ 1. LDP Appointed Justices } \\
\hline & $\begin{array}{l}\text { Majority } \\
\text { vote }\end{array}$ & $\begin{array}{l}\text { Other } \\
\text { LDP } \\
\text { maj. \% }\end{array}$ & $\begin{array}{l}\text { Reform } \\
\text { maj. \% }\end{array}$ & & $\begin{array}{l}\text { Dissent } \\
\text { vote }\end{array}$ & $\begin{array}{l}\text { Oth. } \\
\text { LDP } \\
\text { diss. \% }\end{array}$ & $\begin{array}{l}\text { Reform } \\
\text { diss. \% }\end{array}$ \\
\hline $\begin{array}{l}\text { Majority } \\
\text { vote }\end{array}$ & 1.00 & & & $\begin{array}{l}\text { Dissent } \\
\text { vote }\end{array}$ & 1.00 & & \\
\hline $\begin{array}{l}\text { Other } \\
\text { LDP } \\
\text { maj. \% }\end{array}$ & $-.04(.70)$ & 1.00 & & $\begin{array}{l}\text { Other } \\
\text { LDP } \\
\text { diss. \% }\end{array}$ & $-.05(.61)$ & 1.00 & \\
\hline $\begin{array}{l}\text { Reform } \\
\text { maj. \% }\end{array}$ & $.25(.01)$ & $.57(.00)$ & 1.00 & $\begin{array}{l}\text { Reform } \\
\text { diss. \% }\end{array}$ & $.25(.01)$ & $.57(.00)$ & 1.00 \\
\hline
\end{tabular}

\begin{tabular}{|l|l|l|l|l|l|l|l|}
\hline 2. Reform Appointed Justices & $\begin{array}{l}\text { Majority } \\
\text { vote }\end{array}$ & $\begin{array}{l}\text { LDP } \\
\text { maj. \% }\end{array}$ & $\begin{array}{l}\text { Oth. } \\
\text { Reform } \\
\text { maj. } \%\end{array}$ & & $\begin{array}{l}\text { Dissent } \\
\text { vote }\end{array}$ & $\begin{array}{l}\text { LDP } \\
\text { diss. \% } \\
\text { votent }\end{array}$ & $\begin{array}{l}\text { Oth. } \\
\text { Ref. } \\
\text { diss. } \%\end{array}$ \\
\hline $\begin{array}{l}\text { Majority } \\
\text { vote }\end{array}$ & 1.00 & & & $\begin{array}{l}\text { LDP } \\
\text { diss. \% }\end{array}$ & $.23(.04)$ & 1.00 & \\
\hline $\begin{array}{l}\text { LDP } \\
\text { maj. } \%\end{array}$ & $.23(.04)$ & 1.00 & & $\begin{array}{l}\text { Oth. Ref. } \\
\text { diss. } \%\end{array}$ & $.24(.04)$ & $.40(.00)$ & 1.00 \\
\hline $\begin{array}{l}\text { Oth. Ref. } \\
\text { maj. \% }\end{array}$ & $.23(.04)$ & $.37(.00)$ & 1.00 & & \\
\hline
\end{tabular}

Notes: The dataset includes all en banc decisions published between January 1, 1993 and December 31, 2002 that included either a dissenting or a concurring opinion. $P$-values in parentheses.

Sources: See Table 1.

\section{E. Significance}

1. Introduction. The reformist-appointed justices did not write more dissents. They did not write opinions that the commercial press found unusually newsworthy. They did not write opinions that 
Secretariat editors shunned. They did not vote as a block.

The data tell us all this. But they do not tell us why. In this regard, consider the following four possibilities.

2. Judicial Ideology. At one level, the data suggest that the justices (both LDP and reformist) may see their job as voting the law. Indulging their political preferences they perhaps think illegitimate. If they shun politics and follow the law, the results above follow.

And at some level, the point is surely true. The Japanese public sees a judge's job as enforcing the law. Probably, so do the judges.

For a United States-Japan comparison, however, the point is also irrelevant. Like Japanese voters, American voters (other than law professors, one is tempted to add) similarly see the judicial job as that of voting the law. ${ }^{83}$ So does Judge Harry Edwards. When he writes what he does, he confirms an ethic as deeply held in the United States as in Japan. Many Japanese judges do indeed see political judging as improper-but so do many American judges.

3. Strategic Voting. The Justices' public votes may also reflect private log-rolls. Rather than reflect their true preferences, the votes justices cast in public could also reflect the deals they cut in private. Because the deals involve multiple opinions ("You vote my way on this case; I'll vote your way on the other"), how justices vote in any one case may say little about what they actually prefer. ${ }^{84}$

This "strategic voting" could easily lie behind the hundreds of unanimous five-judge panel cases. ${ }^{85}$ Opinionated jurists do routinely disagree, after all-even in Japan, and even on nonpolitical questions. Poll any five jurists even from the same political party on any 174 random legal questions, and they will seldom agree on 164 .

Whatever the case in the five-judge panel cases, the justices in the en banc cases ${ }^{86}$ are not cutting their deals within political blocks. Instead, if they make any explicit or implicit trades, they seem to

83. See For Republicans, Judicial Appointments Matter More than Iraq, RASMUSSEN REPORTS, May 21, 2008, http://www.rasmussenreports.com/public_content/politics/election_ 20082/2008_presidential_election/for_republicans_judicial_appointments_matter_more_than_ir aq.

84. As a normative matter, vote trading on the bench is roundly condemned. E.g., Evan H. Caminker, Sincere and Strategic Voting Norms on Multimember Courts, 97 MICH. L. REV. 2297, 2333-79 (1999).

85. See infra Table 1, Panel A: Opinions Published by the Supreme Court.

86. See infra Table 3, Panel A: Summary Statistics. 
make them on their own. After all, in most of these cases they split their votes within both the LDP and the reformist blocks. Just as legislative vote trading most often occurs within political parties, ${ }^{87}$ one might expect vote trading on the court to occur among ideological compatriots. At least in the en banc cases of the Japanese Supreme Court, however, that apparently does not occur: if justices swap votes, they swap them individually.

4. Bland Cases. Bear in mind that Japanese courts do not handle as politically charged a set of disputes as the courts in the United States. Japanese courts have not been as receptive to "innovative" claims as some American courts, and-as a result-litigants have not been as eager to bring them. ${ }^{88}$ This is endogenous to the character of the judges. As long as the LDP appointed the justices and they in turn managed the lower courts, politically inclined disputants justifiably saw the courts as unreceptive. ${ }^{89}$ Once Hosokawa and Murayama began appointing justices, however, they might have begun to consider bringing more of the claims we see in the United States.

For the voting patterns in Table 3, however, all this is as irrelevant as it is true. The cases in Table 3 are not a random sample of cases. Instead, they are the cases heard en banc. By definition, they are the politically most highly charged disputes of all: cases in which one of the parties challenged the constitutionality of a statute or regulation. Judicial hostility to political litigation may help explain why the court hears so few disputes en banc. It does not explain why the justices voted as they did in the few cases they did hear en banc.

5. Tenuous Hold. Fundamentally, however, perhaps Hosokawa and Murayama never tried to change the character of the courts. As a LDP politician who had only recently quit the party, Hosokawa did not hold radically different policy preferences from his predecessors. Neither did the other politicians in his coalition. As a Socialist,

87. E.g., Keith T. Poole \& Howard Rosenthal, Patterns of Congressional Voting, 35 AM. J. POL. SCI. 228, 265 (1991) (observing that the "maintenance of party coalitions apparently puts considerable constraint on the extent of internal party dissent").

88. As Professor John Haley put it, "the justices have tended to defer to the political branches of government and the political process rather than craft constitutional mandates themselves.” JOHN OWEN HALEY, THE SPIRIT OF JAPANESE LAW 178 (1998).

89. In the LDP years, a "political" claim would tend to have been brought by an opposition litigant, if only because LDP supporters would have been more likely to enact their policy preferences in the Diet. Opposition supporters litigated because they found their legislative options foreclosed. 
Murayama did hold other preferences, but he governed through a coalition that included the LDP. ${ }^{90}$ Within this coalition, he negotiated from a fundamentally weak position. In the July 1993 lower house election, the LDP had captured 223 of the 511 seats. His Socialists had taken only seventy. ${ }^{91}$

Whatever the reason, Hosokawa and Murayama apparently put judicial change on low priority. Murayama probably lacked the power to push through change without jeopardizing other aspects of his program; Hosokawa may not even have wanted to change the courts. Both premiers apparently focused their attention elsewhere. They could not solidly have altered the courts except through supreme court appointments. But they had not finally appointed a majority of the justices until September 1995, and had not appointed the administratively crucial Chief Justice until November $1995 .^{92}$ Two months later, the LDP re-took control.

Given what Hosokawa and Murayama did (that is, given what they did not do), it stands to reason that the lower courts would not have changed. Given the tenuous reformist hold on government, jurists interested in radical change would have hesitated to join the courts. The government could not credibly have assured them a stable career, even had it tried. For the same reason, sitting judges with reformist preferences would have hesitated to shift their behavior toward reformist positions. The LDP could return, after all-as it soon did. The resurgent conservatives in the courts could then punish them in their careers, and the conservatives in the Diet would reverse their case law by statute.

And even had Murayama hoped to change policy fundamentally, perhaps he would not have worked through the courts anyway. Rather than manipulate the courts, perhaps he tried to implement the

90. See Andrew Gordon, A Modern History of JAPAn: From TOKUGAwA Times to THE PRESENT 323-24 (2d ed. 2009). Murayama abandoned two long-time Socialist positionsopposition to the Self-Defense Force and the defense treaty with the United Statesimmediately upon taking office. See Haruhiro Fukui \& Shigeko N. Fukai, Japan in 1996: Between Hope and Uncertainty, 37 ASIA SURVEY 20, 26 (1997).

91. See GORDON, supra note 90, at 323 (explaining that the Socialists considered forming a coalition with the LDP as "a last best chance to share power").

92. On the tenure of the justices, see ZEN SAIBANKAN KEIREKI SORAN, supra note 16, at 357. Of course, the appointment of the chief justice himself was not indispensable. A prime minister intent on controlling the lower courts could privately assure a sitting Secretary General that he (the Secretary General) would be appointed to the supreme court on the next vacancy if but only if he administered the Secretariat in ways that implemented the prime minister's political agenda. 
Socialist agenda by statute. Perhaps he tried to shift the large bureaucratic apparatus (stacked with three decades of LDP appointees). And within the bureaucracy, perhaps he focused on those ministries most central to his Socialist reform. ${ }^{93}$ Among the ministries, the Ministry of Justice was most closely tied to the courts. Apparently, however, it was not a ministry about which he much cared. Over the course of his short tenure, he cycled three men through the minister of justice slot. All three were LDP politicians. ${ }^{94}$

More basically, perhaps Hosokawa and Murayama thought they could shift the equilibrium in the lower court from political control to political independence. Suppose, for instance, that they thought they had ushered in an era of alternating political control. After all, writes historian Andrew Gordon, "in 1993, most observers predicted movement toward a two-party system. They expected a coherent rival to the LDP would emerge." ${ }^{95}$ If so, perhaps the two dominant parties could choose mutually to keep their hands off the courts as a way of minimizing their losses while out of power. ${ }^{96}$ And in Japan, keeping their hands off the lower courts would necessarily entail a nonpolitical approach to supreme court appointments. ${ }^{97}$

In the United States, though the Democrat and Republican governments politicize the judicial appointments process, they do keep sitting federal judges independent of themselves. By keeping the courts mutually independent, they reduce the political cost of electoral defeat. Because they expect to lose elections from time to

93. Consistent with that principle, he did save the Cabinet Secretariat, the Management \& Coordination Agency, the Ministry of Labor, and the Ministry of Health \& Welfare for Socialist politicians. Beyond those posts, though, he seems mostly to have focused on pork. At various times, he assigned Socialist politicians to the post office, the Ministry of Construction, and the Ministry of Land and Infrastructure.

94. Shigeto Nagano, the first justice minister, began his political career as a member of the LDP in the House of Councillors. See Profiles of Coalition Cabinet Ministers; Justice Minister: Shigeto Nagano, DAILY YOMIURI, Apr. 29, 1994, at 4. His successor, Tomoharu Tazawa, was a LDP member and the chairman of the upper house Rules and Administration Committee of the House of Councillors. See Profiles of Ministers in New Murayama Cabinet, DAILY YOMIURI, Aug. 9, 1995, at 5. Similarly, Tazawa's successor, Hiroshi Miyazawa was a LDP House of Councillor member. See Tazawa Resigns as Justice Minister; Miyazawa Appointed as Successor, DAILY YOMIURI, Oct. 10, 1995, at 1.

95. GORDON, supra note 90 , at 323 .

96. See GinsBURG, supra note 14, at 21-33; Hanssen, supra note 14, at 712; Ramseyer, supra note 14 , at $741-42$.

97. In the United States, the parties can politicize judicial appointments while still keeping the judicial administration politically independent. In Japan, the internal structure of the courts makes that distinction much harder to make. 
time, they find the hands-off-the-courts strategy mutually beneficial. By contrast, the Japanese LDP had not kept the lower courts independent-but neither had it expected to lose power. If Hosokawa and Murayama thought that Japanese parties would begin to alternate in power, ${ }^{98}$ perhaps they hoped to shift the equilibrium in the lower courts from nonindependence to independence. Toward that end, perhaps they deliberately kept their hands off the courts. If this was in fact their calculation, they were wrong ex post-but that fact does not itself render the strategy necessarily irrational ex ante.

\section{CONCLUSION}

Japanese Supreme Court justices enjoy an institutional independence that their lower-court brethren lack. Lower-court judges work within a career structure that rewards them for following the political preferences of the long-time ruling LDP. That LDP briefly lost power in the mid-1990s, but for the lower-court judges little changed.

Had the reformist premiers who temporarily replaced the LDP in the 1990s hoped to change the courts, they would have begun with the appointments to the supreme court. As the LDP-appointed justices retired, they would have named jurists who shared their reformist instincts. Precisely because of the institutional independence of the court, those changed appointments would have generated changed opinions: the new justices with reformist policy preferences would have written opinions different from those of their LDP predecessors.

Yet the reformist-appointed justices did not write different opinions. They did not write more dissents. They did not write more newsworthy decisions. They did not write opinions that antagonized Secretariat editors. And they did not vote as a block. Apparently, the reformist premiers did not appoint justices with different political preferences from their predecessors.

98. See GORDON, supra note 90, at 323. 